\title{
The Antiochene Synod of AD 363 and the Beginnings of Neo-Nicenism
}

\author{
by Johannes Zachhuber
}

The synod held by Meletius and some of his followers at Antioch in 363 has, in recent times, not found much scholarly attention ${ }^{1}$. It is here, however, that we find for the first time original non-Nicenes adopting the formula of Nicaea, and thus the event marks the beginning of neoNicenism if this term is allowed to stand for the emergence of a new Nicene party, which, in my view, should be its least controversial sense ${ }^{2}$. Notably, this Antiochene synod would appear to be more relevant in this regard than the more famous Alexandrian council of the previous year; the latter had taken place under the auspices of Athanasius and may perhaps be said to document the Alexandrian pope's ambitions rather than those of his supposed counterparts. Indeed, as is well known, the participation in the latter event of a Meletian delegation is a notorious problem in itself $f^{3}$, but even if their presence were granted, their influence on the formulation of the Tomus would have been limited.

The present article therefore proposes to analyse the information available about that Antiochene synod with regard to its impact upon the early history and theology of this neo-Nicene party.

1 Recently H.Ch. Brennecke has devoted some attention to this event: Studien zur Geschichte der Homöer, BHTh 73, Tübingen 1988, 173-178; id., Erwägungen zu den Anfängen des Neunizänismus, in: D. Papandreou/W.A. Bienert/K. Schäferdiek (Eds.), Oecumenica et Patristica. FS W. Schneemelcher, Stuttgart/Berlin/Köln 1989, 241-257. Cf. also: V.H. Drecoll, Die Entwicklung der Trinitätslehre des Basilius von Cäsarea. Sein Weg vom Homöusianer zum Neonizäner, FKDG 66, Göttingen 1996, 16-18; R.P.C. Hanson, The Search for the Christian Doctrine of God, Edinburgh 1988, 581-582; 651-653. Of earlier literature F. Cavallera, Le schisme d'Antioche (IVe-Ve siècle), Paris 1905, 99-127; H.A1. Gwatkin, Studies of Arianism, Cambridge ${ }^{2} 1900,230-231$ and E. Schwartz, Zur Kirchengeschichte des vierten Jahrhunderts, ZNW 34, 1935, (129-213) 167-168 are still valuable.

I would wish to express my gratitude to Hartmut Leppin, Giles Gasper and David Robertson for reading drafts of this essay and for their most helpful comments and criticism.

2 I shall say little in this article about the related question of whether or in what sense there is a 'neo-Nicene trinitarian theology'. In particular, I shall leave aside the intricate problem of the neo-Nicene differentiation between ousia and bypostasis, its origin and its relation to the neo-Nicene movement. For both cf. now: R.M. Hübner, Zur Genese der trinitarischen Formel bei Basilius von Caesarea, in: M. Weitlauf/P. Neuner (Eds.), Für euch Bischof - mit euch Christ. FS F. Kardinal Werter, St. Ottilien 1998, 123-156, where a most helpful account of the recent vicissitudes of that debate is offered. von Alexandrien, ZNW 66, 1975, (194-222) 205f. n. 35. See further at $n$. 44 below. 
1.

The chief source for the synod is Socrates' Church History ${ }^{4}$. From his account it appears that a number of bishops convened at Antioch on the occasion of Jovian's accession (27 June 363 ) in order to compose and present to the new emperor their own credal formula. The exact date of the event is unknown ${ }^{5}$. Socrates seems to imply that it coincided with the emperor's stay at Antioch ${ }^{6}$, i.e. some time between the end of September and early November'. For reasons which will become obvious in due course it is indeed most likely that the synod took place in late October or early November.

All major participants of the synod had a 'homoian' past, as $\mathrm{H}$. Ch. Brennecke has pointed out $^{8}$ : the list of signatories to the synodical epistle includes, besides Meletius, Eusebius of Samosata, Pelagius of Laodicea, and others who had signed the Constantinopolitan Creed of AD 360 and, in their majority, owed their bishopric to that same council. Why, then, do they now confess the Nicene Creed? Socrates' report hints at oppor-

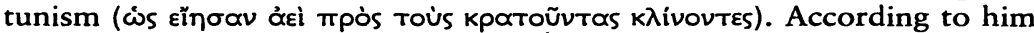
the 'Acacians' would have learned that the new emperor held Meletius in high regard. Thereupon, as true turncoats, they would have gathered behind the emperor's protégé and embraced his creed immediately.

Naturally there is no knowing about the motive behind the decision of each single participant of that synod; as for the better-known bishops mentioned above, however, opportunism does not commend itself as the very best explanation possible. They were to persevere in their Nicene allegiance throughout the period of homoian domination which ensued, lasting almost two decades. Since Socrates himself would normally be unlikely to level so severe a charge against allies of his hero, Meletius, it may be allowed that his judgment is here taken over from his source, the homoiousian Sabinus, whose dislike for homoians and Nicenes alike need not surprise us?.

4 Socr., h.e. III 25,6-18 (GCS Sokrates, 225,27-227,11 Hansen). Sozomen's account at h.e. VI 4,6-11 (GCS Sozomenus, 241,4-242,8 Bidez/Hansen) largely corresponds but without the polemics from Sabinus (see below at n. 9); cf. also: Hier., chron. ad AD 364 (GCS Eusebius VII, 243,21-24 Helm).

5 Cf. H.Ch. Brennecke, Homöer (see note 1), 173 f. n. 97.

6 Socr.; h.e. III 25,8 (226,5 H.).

7 O. Seeck, Regesten der Kaiser und Päpste für die Jahre 311 bis 476 n.Chr., Stuttgart $1919,213$.

8 H.Ch. Brennecke, Homöer (see note 1), $174 \mathrm{n}$. 99. No evidence is to be gained this way for the frequent claim of a homoiousian background of the synod (e.g. W.-D. Hauschild, Die Pneumatomachen, unpublished D.Phil. dissertation, Hamburg 1967, 188f.).

9 H.Ch. Brennecke, Homöer (see note 1), 174; cf. W.-D. Hauschild, Die antinizänische Synodalaktensammlung des Sabinus von Herakles, VigChr 24, 1970, (105-126) 110. 
The most likely explanation for this renewed interest in the Nicene Creed would appear to be the emergence of the neo-Arianism of Aetius and Eunomius ${ }^{10}$. This link is suggested by the Antiochene synodical epistle itself ${ }^{11}$ as well as by the timing of the move. The connection between Nicaea and Arianism was clearly perceived also, e.g., by the homoiousian authors of the Epistula Sirmiensis: ... in synodo, quae apud Nicaearn fuit, coacti patres nostri propter eos qui creaturam Filium dicebant, nomen bomousii indidissent ${ }^{12}$. It was cogent, therefore, that the re-emergence of that sect, more radical even in their subordinationism, should prompt a reappreciation of the one creed that had been specially designed to combat Arianism.

A special problem, admittedly, is posed by the alleged presence at the synod of Acacius of Caesarea, one of the architects of the Constantinopolitan settlement of 360 . Perhaps his name has to be deleted from the list, as Brennecke suggests ${ }^{13}$. Even if we were to allow the possibility of such opportunism ${ }^{14}$, his place on the list as sixth in order is not easily accounted for. It seems possible that the original had (or implied ${ }^{15}$ ) "Acacius of Tarsus' instead who, according to Philostorgius ${ }^{16}$, was, like Meletius, one of Acacius' 'Nicene' nominations in 360 .

As part of his legitimate attempt to deconstruct the historical myth of a 'Nicene' Jovian", Brennecke has suggested also the discarding of the claim that this emperor protected Meletius ${ }^{18}$. However this, I think, is not as easily accomplished as Brennecke wishes us to believe. Socrates explicitly states that the bishops rejoined Meletius 'seeing that he was honoured

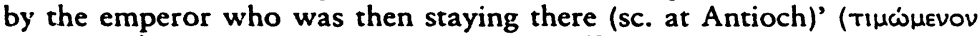

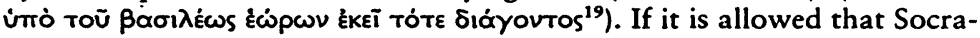
tes' polemics against our synod is taken from a fourth-century source, then there was most likely some reason justifying this kind of slander on the part of an unsympathetic contemporary. In Socrates' reading, of course, the implication is that both, Jovian and Meletius, are Nicene. For Sabinus, however, - granted that Brennecke's view of Jovian is in principle

So also: H.Ch. Brennecke, Erwägungen (see note 1), 249.

Socr., h.e. III $25,15(226,25-27$ H.).

Ap. Hilar., syn. 81 (PL 10, 534 B).

H.Ch. Brennecke. Homöer (see note 1), $175 f$.

Cf. also Socr., h.e. IV $2,3(231,1$. H.), where he is paired with Eudoxius again.

15 only.

16

Philost., h.e. V 1 (GCS Philostorgius, 66,23 Bidez/Winkelmann).

H.Ch. Brennecke, Homöer (see note 1), 178-181.

H.Ch. Brennecke, Homöer (see note 1), 174 n. 99. Cf. also: H. Leppin, Von Constantin dem Großen zu Theodosius II. Das christliche Kaisertum bei den Kirchenhistorikern Socrates, Sozomenus und Theodoret, Hyp. 110, Göttingen 1996, 86-90. 
accurate - the Nicenism of the synodical epistle would not in itself have made its authors suspect of opportunism. At the same time, his charges against those 'Acacians' would be difficult to account for if they had not exposed themselves to this suspicion at all. If Meletius, in 363, was only the head of some staunch followers without influence in Antioch, it is difficult to see why bishops gathering around him should be seen by anybody as opportunistic turncoats. It appears, then, that by far the most likely reason for such a charge is that Jovian had at some point indicated sympathies towards Meletius. This is in accordance with Socrates' wording; it also conforms to more general reasoning: a newly proclaimed emperor without much of a power base in the Empire, Jovian would have been likely to court as many potential allies as he could. He received Athanasius: could he not, in a similar way, have received and supported Meletius too while he was staying at Antioch? This would not, of course, bring back the 'Nicene' Jovian; it could explain, however, not only the charge of opportunism against Meletius' allies in 363 but also the fact that the synodical letter does not even refer to an expected or desired restitution of Meletius. Self confidently, the latter signs on top of the list as 'bishop of Antioch'20. I take it therefore that, as in the case of Athanasius, the Emperor Jovian in some way accepted Meletius' claim to the see of Antioch, and that this act preceded the Antiochene synod under consideration here.

\section{2.}

The centrepiece of Socrates' report about our synod and its only part whose authenticity is practically undoubted is the letter written from that synod to the emperor. I shall now proceed with a close reading of this document in order to ascertain its place within the framework of the doctrinal development of the age.

The letter starts with an appeal to the emperor's love of concord and

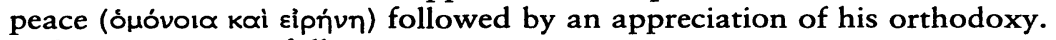
It then goes on as follows:

... we submit to Your Reverence that we accept and hold to the creed of the holy Council of Nicaea which was assembled a long time ago. And when we mention the word in it which appears strange ${ }^{21}$ to some, the homoousion, it has received a sound interpretation among the fathers, signifying that the Son was begotten from the ousia of the Father and that he is like the Father in ousia; it does not mean that any passion occurred in the ineffable generation, nor was the word ousia taken by the fathers in a certain Greek use, but to refute the "from nonexistence" which Arius impiously dared to apply to Christ, and which the

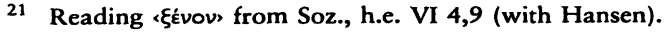


anomoians, who are around today, shamelessly parade in an even more desperate and daring manner to the injury of the church's peace ${ }^{22}$.

The first observation that should strike us is the way the letter refers to Nicaea: it is not only recognised as an orthodox Council, but it is the one and only synod to be spoken of. No mention whatever is made of any of the many intervening councils. Note the difference to the opening section of the synodical written by the homoiousian synod at Ancyra in 358: there $\mathrm{e}^{23}$ the bishops had carefully constructed a list of synods as a pedigree of their orthodoxy. In the view of the present document's authors Nicaea seems to be sufficient; it is difficult not to see in this fact a parallel to Athanasius' position since the latter half of the 350 's'.

If thus the bishops are in agreement with, perhaps even dependent on, Athanasius as regards this insistence on the sufficiency of the Nicene Creed, it is otherwise less obvious what their theological Nicenism amounts to. It has sometimes been argued that the bishops' confession of the Nicene Creed is chiefly characterised by a fundamental deviation from its genuine interpretation ${ }^{2 s}$. This deviation would concern the understanding of the term homoousios, the only element of the Nicene Creed which the Meletian bishops deem in need of interpretation. Since the Nicene Creed does not interpret itself, the 'genuine interpretation' of the homoousion would be that of Athanasius as no other theologian of his generation yields much material for this problem. Thus the question to be posed is this: does the interpretation the bishops give of the homoousion deviate from, or even contradict that of, Athanasius?

To begin with, it is clear that in the view of those Meletian bishops the bomoousion is the only serious theological difficulty about the Nicene Creed. This is in a sense not very surprising: many witnesses, from Eusebius of Nicomediaa ${ }^{26}$ to Basil of Caesaraea ${ }^{27}$, agree that this one word

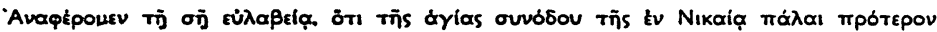

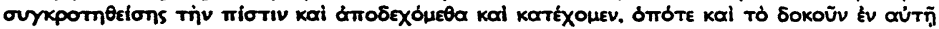

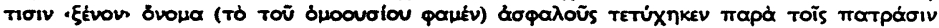

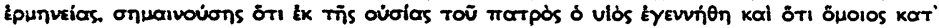

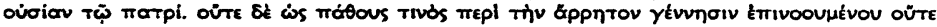

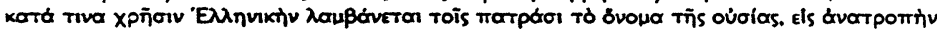

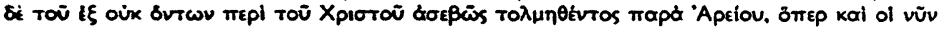

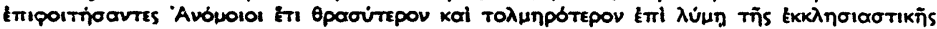

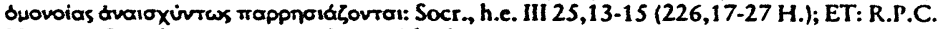
Hanson, Search (see note 1), 581 (with changes).

23 Ap. Epiph., haer. 73,2,2-3 (GCS Epiphanius III, 269,3-15 Holl/Dummer).

24 Cf., e.g., syn. 6 (Werke 21, 234,14-30 Opitz); tom. 3 (PG 26, 797 C-800 A).

2s E.g.: H.M. Gwatkin, Studies (see note 1), 230f.; H. Lietzmann, Geschichte der Alten Kirche, vol. 4: Die Zeit der Kirchenväter, Berlin 1944, 2f.; H.Ch. Brennecke, Homöer (see note 1), 176: "ganz homöusianisch".

26 Ap. Ambr., fid. III 15 = Urkunde 21 (Athanasius, Werke 3/1, 42 Opitz); cf. also Urkunde 22, 7 (44,1-8 O.).

27 E. 214,3 (Lettres 2, 204,1-7 Courtonne). 
was at the centre of the controversy about acceptance or rejection of the Nicene Creed. Since many patristic scholars, however, maintain that most Easterns could not accept Nicaea on account of its alleged one-hypostasis theology, it may be worthy of mention that the present document shows no awareness of this particular problem. This, I think, indicates that its authors felt Nicaea to be capable of interpretation in this regard.

One might perhaps argue that, in 363 , the homoousion was difficult to accept for those bishops precisely on account of its close association with a unitary theology. To hold the homoousion would thus be tantamount to confessing one hypostasis. This once influential view, however, is now generally and, I think, rightly rejected ${ }^{28}$. As for the term's use at the present place there is nothing indicating that the misgivings of 'some' towards the homoousion were due to its alleged Sabellianist implications.

The suspicion that the authors give a novel interpretation to the homoousion must rely, then, on those four caveats with which the bishops wish to safeguard the orthodox understanding of the bomoousion. These can be divided into two pairs of which the first contains two possible misconceptions of the Nicene phrase while the latter gives a positive explanation of what homoousios should stand for.

Let us look at the latter pair first. The bishops urge that homoousios means that the Son was 'begotten of the Father's ousia' and that he is 'like the Father in ousia'. It is the latter phrase in particular which has aroused charges of un-Nicene theology. As for the former, it would seem evident that the text attempts to interpret the Nicene Creed with its own words:

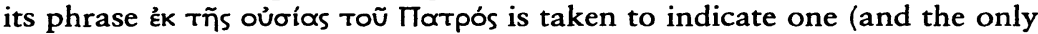
acceptable) interpretation of the homoousion. Which interpretation? While an ultimate answer cannot be given as yet, it would appear most likely that the authors wished to endorse a derivative understanding of the Nicene watchword: the Son is homoousios with the Father in so far as he is begotten of the Father's ousia. Such an interpretation excludes, as the text itself notes, any notion of the Son as a product ( $\pi \circ i \eta \mu \alpha)$ or of his

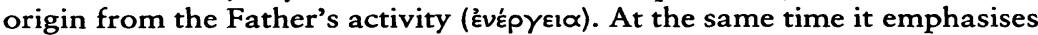
what Stead has called - with regard to Athanasius - 'a built-in asymmetry' in the intratrinitarian relationship ${ }^{29}$ : the Son is God qua derivation from the Father, he is not by himself a second divine principle. If the present interpretation of this caveat is accepted, then this latter notion must be paramount. For, employing the homoousion would in few cases incur the charge of Arianism, while the charge of introducing two ópxoí was, as we know, a frequent one against Nicenes of all times ${ }^{30}$.

28 Cf. G.C. Stead, Divine Substance, Oxford 1977, 223-266; accepted by R.P.C. Hanson, Search (see note 1), 198-202.

29 G.C. Stead, Substance (see note 28 ), 260.

30 Cf. R.D. Williams, The Logic of Arianism, JThS 34, 1983, (56-81) 66-70. 
We find it perhaps not equally easy to see how the Meletian bishops can maintain that 'like in ousia' could be a legitimate interpretation of the Nicene homoousion let alone one implied by the fathers of Nicaea themselves as the text seems to claim. A sharp juxtaposition of 'the same' and 'like', however, needs the unitary interpretation of the homoousion to be maintained: admittedly, when Father and Son are thought to be - in Marcellan language - one person, to say that homoousios means 'like each other' would practically amount to a reversal of its genuine meaning. Otherwise, 'like in ousia' could, I believe, be, possibly, an interpretation of the homoousion emphasising that (1) Father and Son are two different subjects and in this sense 'like' each other, and (2) that their relationship concerns ousia, not, e.g., energeia. Of what kind this substantial relationship is, is a separate question whose answer is not, I think, pre-empted by this formula. It seems to me that onolos Kor' oúriov could well mean 'they are like each other in so far as they share one and the same ousia'. One should not ignore that likeness-terminology is here employed to interpret the bomoousion, not to replace it.

If the interpretation the authors give of the homoousion does thus not appear a priori illogical, is it un-Athanasian? The question needs to be asked seriously with regard to the use of 'like in ousia' only. It would appear indubitable that the derivation of the Son from the Father's ousia is a central part of Athanasius' trinitarian theology and also vital for his understanding of the bomoousion.

Athanasius, it is true, in his later works frequently expresses the view that likeness-terminology is less appropriate than the homoousion ${ }^{31}$. In his earlier works, on the other hand, he had used likeness-terminology himself for what appears to be a very similar, if not the same theology ${ }^{32}$. It must be noted that, where he criticises this terminology, he argues against people who reject the homoousion in favour of likeness-formulas. His intention there is to show the necessity of the homoousion and thus the indispensability of the Nicene Creed. However, in a well-known passage he admits that 'like in ousia' plus 'of the Father's ousia' is equivalent to confessing the bomoousion ${ }^{33}$. If Athanasius concedes this to people who reject the homoousion, the homoiousians, it must be allowed to infer that the use of these two formulas to interpret Nicaea is not contrary to his theological intent. In fact, the combination of opolos kot' ovoiorv and हk

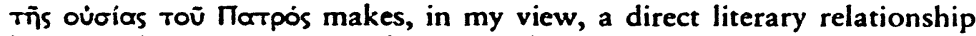
between the present text and De synodis 41 likely. It would also appear that the explanation offered above of 'like in ousia' is in line with the

\footnotetext{
31 E.g. at syn. $53(276,24-277,5$ O.).

32 E.g. at Ar. I 20,1,3 (Werke 1/1, 129 Tetz); 21,2,7 (130 T.); III 26 (PG 26, 377 A). Cf. G.C. Stead, Ar. Homousios, RAC 16, Stutrgart 1994, (364-433) 416.

33 Syn. 41,3-4 (267,3-11 0.).
} 
Athanasian position. There is thus, up to this point, no reason to believe that the interpretation the present text gives of the Nicene Creed would have offended Athanasius.

We have to consider now the two negative caveats the letter makes in order to exclude possible misconceptions of the homoousion. Of these, one is easily explained; to exclude the possibility that homoousios invokes the notion of 'passion' with regard to the divine generation is a concern which can be traced back to the Council of Nicaea itself. Eusebius reports that Constantine, who insisted on the insertion into the Creed of the

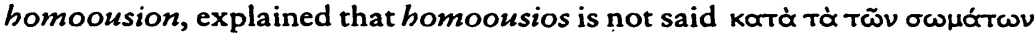
$\pi \alpha \dot{\theta} \eta^{34}$. The mention of 'passions' is recurrent in statements of the Eusebian party ${ }^{35}$, and in 358 the homoiousian bishops employ this problem for the justification of their use of creation-terminology alongside the generation paradigm $^{36}$. It is not surprising, then, that the present text, which accepts the homoousion and the generation paradigm exclusively, defends its theology against possible charges of that kind.

One might argue that a materialistic misunderstanding of the homoousion would be a rather base one: it should have been clear to anybody that analogies in general must be applied to the divinity only with a grain of salt, and that the Father does not 'beget' the Son in a sexual act would seem equally obvious. Yet the present text mentions 'passion' only, which could be understood to refer to any sort of passivity to which the Father might be subject. This may include notions of a quasi-automatic or necessary procession of the Son from the Father, which would be seen to impinge on the Father's omnipotence ${ }^{37}$.

$\mathrm{Be}$ this as it may, far more cryptic than this caveat is the authors' remark that the word ousia must not be conceived of in a certain 'Greek use'. Since, as far as I see, all the bishops assembled in Antioch speak Greek, we can safely exclude the possibility that 'Greek' refers to any peculiarity of the Greek language in comparison with, e.g., Latin or Syriac. It would seem most likely, then, that 'Greek' refers to the pagan culture of late antiquity, a use dear to the members of the tertium genus since New Testament times ${ }^{38}$. More precisely, it would have been philosophers whom the present text has in mind as they are the most likely candidates for a defined use of the term ousia. This finding, however, is as yet no great help since it is clear that there was not one meaning of ousia generally accepted by philosophers of that time.

34 Eus., ep. Caes. = Urkunde 22,7 (44,4 O.).

35 E.g. in the first Sirmian Creed of 351 (Ath., syn. $27=$ A. Hahn, Bibliothek der Symbole und Glaubensregeln der Alten Kirche, Breslau ${ }^{3} 1897$ [ $=$ Hildesheim 1962], $\$ 160$, p. XXV).

36 Epiph., haer. 73,3,5-8 (271,22-272,17 H./D.).

37 For this problem cf. the Macrostich Creed (Ath., syn. 26 = A. Hahn, Symbole, $\$ 159$, VIII).

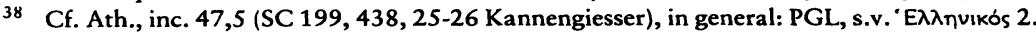


It is interesting that Athanasius in De Synodis employs very similar language. With regard to one argument employed by his opponents against the bomoousion he remarks that this is based on the 'understanding

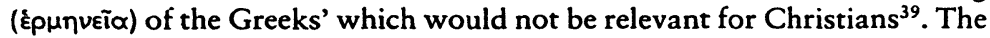
argument is this:

They say, as you write, that one must not call the Son homoousios with the Father since he who says homoousios implies the existence of three: an antecedent substance and the two bomoousioi that are generated out of it. From this they conclude: 'If the Son be homoousios with the Father, a substance will necessarily be antecedent to them from which they both were generated. Thus they will not be Father and Son, but mutually collaterals. ${ }^{40}$

The 'Greeks', then, would be Platonists who maintain that the unity of two things can only be guaranteed by positing an entity which is ontologically prior to both of them. This was, indeed, one of the most frequent arguments against Nicaea and its theology ${ }^{41}$. It implies that, by using the phrase homoousios, Father and Son become ontologically co-ordinate collaterals. Athanasius denies this consequence; he insists that homoousios denotes also and, indeed, more properly a derivative relationship: in the example of his opponents the antecedent ousia and either of its two derivatives would also be homoousios.

Perhaps the characterisation of the present argument against the homoousion as that of 'the Greeks' can be traced back even behind Athanasius. It is clear that one of his chief sources for this kind of material in $D e$ Synodis was the Epistula Sirmiensis, the document produced by the homoiousian bishops in 359 for the emperor and his court bishops to explain the difference between homoousios and homoiousios. According to Hilary's report about this document it must have contained the very argument cited by Athanasius at De Synodis 51. With regard to this argument Hilary himself remarks:

But this sense (sc. of homoousios) is profanus and should be universally rejected by the Church'2.

Profanus could be a way of rendering 'Greek' (Hilary is not translating here) in the meaning discussed above (= 'pagan'); the agreement of Athanasius and Hilary would, then, weigh in favour of an origin of this characterisation with the homoiousians.

39 Syn. 51,4 (275,4-5 0.).

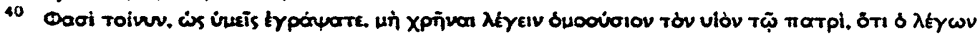

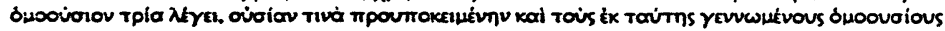

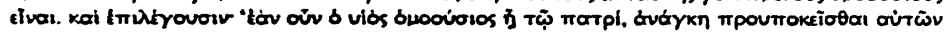

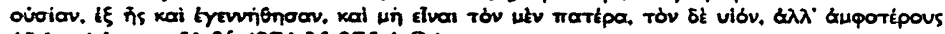

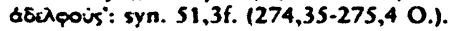

4 Cf. R.D. Williams, Logic (see note 30), 66 and P. Widdicombe, The Fatherhood of God from Origen to Athanasius, Oxford 1994, 172.175.

42

Syn. 81 (PL 10, 534 B). 
Whether the Meletian bishops found it in the Epistula Sirmiensis or in De Synodis, I take it that the 'Greek use' of ousia refers to this same problem: the homoousion must not be thought to imply the existence of two co-ordinate beings; the derivative use, endorsed by Athanasius, is insisted on. This, of course, is in line with their emphasis on the phrase 'of the Father's substance'.

In summary, then, the explanation the present text gives of the use and meaning of the Nicene homoousion cannot be said to contradict either the express doctrine of the Nicene Creed or its interpretation by Athanasius from the latter half of the 350's. In line with Athanasius, homoousios is understood to stand for a derivative relationship between Father and Son. This relationship is defined solely on the basis of generation; any mention of 'creation' is dropped. The caveats made can all be interpreted as safeguarding this Nicenism against its more common criticism. There is no reason to think that Athanasius could have been offended by this text; on the contrary, it would appear likely - particularly in view of the parallels with De Synodis - that its authors drew directly on the Alexandrian patriarch. Did they, then, aim at a rapprochement with the Alexandrian party?

3.

This might appear an appealing conclusion, eventually salvaging the traditional picture of a Nicene 'nucleus' around Athanasius to which were then added successive 'layers' of converts from the 'semi-Arian' camp. It would appear, however, that historical facts as they can be gathered from extant documents of that period forbid this neat theory. There is, to put it in a nutshell, no evidence in those sources that Meletius had, prior to 370 , any interest in establishing communion with Athanasius; in fact, the contrary seems to have been the case. The remainder of this article will be taken up by an attempted reconstruction of the events in 363, with a brief glance at the preceding year, to substantiate this view. It would indicate that Meletius, in the footsteps of the Eastern bishops of the preceding generation $^{43}$, made a clear distinction between Athanasius the theologian and his role in church politics. Whatever Meletius' reasons for this may have been, I shall argue that for the development of neo-Nicenism in the 360 's the idea of a political alliance with Alexandria was of no importance; this changed only with Basil's entering the stage in 370 .

Any account of the interaction between Athanasius and Meletius must start with the Alexandrian synod of 362 . Most scholars view this event as a first step towards a rapprochement between the two bishops with Athanasius generously offering his mediation between Meletius and the

43 Cf. R.P.C. Hanson, Search (see note 1), 254 f. 
ardently Nicene Paulinus of Antioch ${ }^{44}$. The truth is that there are no indications in the Tomus ad Antiochenos ${ }^{45}$ that Meletius or any of his followers was actively engaged in ${ }^{4}{ }^{46}$. My reading of it is that Athanasius, in line with an approach that first comes to the fore in De Synodis 41, attempted to forge an alliance with minority bishops in the East ${ }^{47}$. Chances for this would seem to have been enhanced with the emergence of a new Nicene community under the deposed Meletius at Antioch. Nothing in the Tomus, as far as I can see, prevents the assumption that Meletius by that time was Nicene, as he himself understood it. Paulinus (and Apollinarius too) probably disagreed; but that the argument about the use of hypostasis-terminology, as reported in Tomus 5 and 6 , is related to this conflict is not by any means evident from the text as it stands. It rather is an inference from information we possess from the 370's. The contemporary anti-Meletian polemics of the ps.-Athanasian Refutatio hypocriseos Meletii et Eusebii Samosatensis as well as Apollinarius' letter to Basil ([Basil], ep. 364; on both texts see below) make no mention of this issue; neither, as we have seen, does the Meletian synodical of the following year. All this together with the lack of positive evidence in favour of the presence of a Meletian delegation at Alexandria should suffice, to my mind, to discard the traditional interpretation. Whoever the three-hypostases people at Alexandria were - and I admit that the question thus raised is not easily sertled - they were not, in all likelihood, envoys of Meletius.

There is no known reaction to this synod by Meletius. He probably did not do so. In 363 we find Athanasius still favourable towards the Antiochene bishop, an attitude that prevails until at least November of that year. The events of this time can be reconstructed with an unusually high degree of precision. This has been done elsewhere, and there is little to be added $^{43}$. From a combined reading of the index of Athanasius' festal epistles $^{49}$ and the Historia acephala ${ }^{50}$ it is clear that Athanasius left his

Most recently M. Tetz, Nikäische Orthodoxie (see note 3); H.Ch. Brennecke, Erwägungen (see note 1), $244 f$.

The most comprehensive account to date of this document is: $M$. Tetz, Nikäische Orthodoxie (see note 3). The traditional, 'neo-Nicene' interpretation of this text (cf. for this view most recently: Chr. Markschies, ... et tamen non tres $\mathrm{Dii}$, sed unus Deus ... in: W'. Härle/R. Preul [Eds.], Trinität, MJTh 10, Marburg 1998, [155-179] 174-176) has now been challenged by V.H. Drecoll, Entwicklung (see note 1), 18f. and R.M. Hübner, Trinitarische Formel (see note 2), 145-147.

Cf. J.-M. Leroux, Athanase et la seconde phase de la crise arienne, in: Ch. Kannengiesser (Ed.), Politique et théologie chez Athanase d'Alexandrie, Paris 1974, (145-156) 151-154; R.P.C. Hanson, Search (see note 1), 642.

This pace J.-M. Leroux, loc. cit. 384.389. Index 35 (SC 317, 264-266 Albert/Martin). 
exile in the desert as soon as the news of Julian's death and Jovian's accession had reached him. From there he went to Alexandria where it was at that time still dangerous for him to stays1; he left the city on 6 September towards Hicrapolis where he met with the new emperor and was received favourably. He then went on to Antioch where he, apparently, stayed until early February 364 , as on 14 February he arrived again at Alexandria.

For the present purpose the time Athanasius spent at Antioch is of intercst. With the help of some texts which scholars so far have either chosen to disregard or, at least, have failed, in my view, to put into their appropriate context $I$ hope to arrive at a more accurate picture of those four months. The first piece of evidence is a fragment of a letter Athanasius wrote (to Alexandria, apparently, though this is not explicit) from Antioch ${ }^{52}$. It is clear that this letter cannot have been written earlier than November because the extant fragment refers, immediately before breaking off, to the first petition to the emperor of the Alexandrian Arians, Lucius and Bernicianus, which is said in the text to have taken place on the third Athor (30 October $)^{53}$. If we are allowed to assume that the legendary accounts of those petitions, contained in the Athanasian corpus ${ }^{54}$, are correct in describing successive petitions and, further, that their author drew on the very letter by Athanasius of which we possess the aforesaid fragment, then this letter could hardly have been written before the latter half of November.

This letter seems to presuppose the Meletian synod, but as a very recent event; Athanasius, apparently, has not yet had a chance to read any of its documents. The synod would thus have taken place some time in late October, if not early November:

I ask you, then, when they publish their writings, do not ridicule anyone, nor laugh any longer at those who have earlier spoken to fight against us. For it is not you from whom such a blame is to emanate, nor is it any human being; but it is God from whom this emanates ${ }^{5 s}$.

We here find Athanasius apparently determined to do all he can to pave the way for those new Nicenes into the old Alexandrian party, while he is aware of reservations, perhaps resistance against this course amongst his friends.

51 Cf. hist. Ath. 4,4 (152,16-8 A./M.).

s2 Ath. ep. fest. 36 (CSCO 150, 69,20-71,10 Lefort). The writing is not a festal epistle: fragment 1 is spurious (A. Laminski, Der heilige Geist als Geist der Gläubigen, Leipzig 1969,115 ); there is no obvious connection between this and fragment 2 (M. Tetz, Art. Athanasius, TRE 4, Berlin/New York 1979, [333-349] 341,49-51). Nothing indicates that the latter, to which reference is here being made, is linked with Easter. - For the Coptic I am relying on the expertise of Mr B.W.Yoo.

53 Ath., ep. fest. 36 (71,7-9 L.).

54 PG 26, 820-824.

ss Ath., ep. fest. 36 (70,19-24 L.). 
In mid-November, then, Athanasius still appears confident that a reconciliation with Meletius is at hand. This is crucial to observe because we know that Athanasius' attitude must have changed while he was still at Antioch. This is the episode well known from Basil, who had much occasion to deplore it:

The most blessed Pope Athanasius also, stopping on his way from Alexandria (sic!), especially desired that communion be established between him and Meletius, but through malice of counsellors their union was put off until another time. Would that it had not been so ${ }^{56 !}$

This Basil writes to Epiphanius. Elsewhere, in a letter to Meletius himself, he is more blunt as to the cause of the rupture:

He himself (sc. Athanasius) is said to have made every effort to unite with us, and, on his part, to have done all in his power; but he is now grieving, they say, because on the occasion in question he was sent away without communion, and because the promises which were made to him remain even yet unfulfilled ${ }^{57}$.

The context of the latter passage is Basil's explanation to Meletius that any attempt on his, Basil's, part to ask for Athanasius' intercession at Rome on behalf of the Easterns would be doomed as long as Meletius himself has not made a move towards the establishment of communion with the Alexandrian patriarch. Although Basil appears to depend on hearsay (cf. his erroneous assumption in his letter to Epiphanius about Athanasius' itinerary!), we must assume his information to be basically accurate; otherwise, he would hardly have written to his beloved and honoured friend, Meletius, like this.

What precisely happened between the two bishops we have no means of ascertaining. In particular, I must confess ignorance with regard to the promises mentioned. If Basil wishes to indicate that at any point negotiations between Meletius and Athanasius were poised to succeed, then he either had information available to him which we no longer possess, or he has decided to interpret his information diplomatically in order to coax Meletius into some sort of contact with the Alexandrian bishop.

Be this as it may, what would appear evident is that, at some point during Athanasius' stay at Antioch, Meletius made his rejection of the Alexandrian so unequivocal as to make the latter revoke his interest in

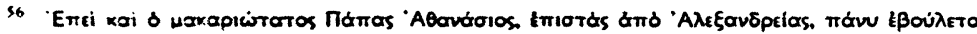

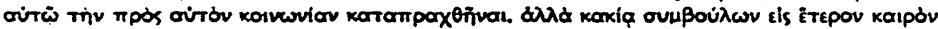

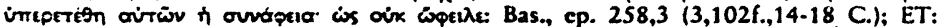
St. Basil, The Letters. Translated by R.J. Deferrari, LCC, London/Cambridge ${ }^{3} 1961 / 62$, vol. 4, 43.

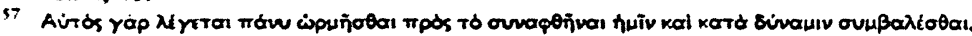

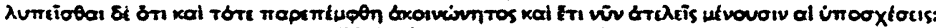
Bas., ep. 89,2 (1,144,6-8 C.); ET: Deferrari, Letters, vol. 2, 121. 
communion with the Antiochene bishop. We have no indication that Athanasius ever reversed that attitude.

Whatever other informers Basil may have had about those events, there is one we know of, Apollinarius. It is his testimony, contained in a letter to Basil, to which we must turn now ${ }^{58}$. This text is relevant as it represents independently a further perspective on the events of this time, that of Athanasius' traditional allies in the East. Understandably, they were thoroughly averse, even hostile, to any rapprochement between Athanasius and the Meletian party. Apollinarius writes of

so great a war (that) has broken out against religion. And we, as if in the midst of battle-line, are shouting to our comrades on account of the violence of the enemyss.

While de Riedmatten had already recognised that the epistle belongs to the reign of Jovian ${ }^{60}$, the line quoted misled Hauschild to assign to the writing a date in 365 assuming a reference to Valens' restoration of homoian rule $^{61}$. Yet the text is explicit in its reference to the Meletian synod. It writes of those who had once been openly opposed but now

... devise the contradiction (to Nicaea) in guise of an interpretation. It was herein that occurred the villainous destruction of the homoousion, the pretext being that the term should not be understood in a certain Greek 'use'62, and the substitution of homoousios by 'like in ousia' ...63.

The letter then goes on with an argument against this latter understanding of the homoousion. The use of 'likeness' would suggest the relation of, e.g., a statue to the emperor and thus be altogether inappropriate ${ }^{64}$. This

I take the correspondence to be genuine; cf. $\mathrm{H}$. de Riedmatten, Basile de Césarée et Apollinaire de Laodicée, JThS 7, 1956, 199-210; 8, 1957, 53-70; R.M. Hübner, Basilius von Caesarea und das Homoousios, in: L.R. Wickham/C.P. Bammel (Eds.), Christian Faith and Greek Philosophy. Essays in Tribute to George Christopher Stead, Leiden 1993, 70-91. Now pace: R. Pouchet, Basile le Grand et son univers d'amis d'après sa correspondance, Rome 1992, 112-114. H.J. Vogt holds ep. 364 to be spurious: Zum Briefwechsel zwischen Basilius und Apollinaris. Übersetzung der.Briefe mit Kommentar, ThQ 175, 1995, (46-60) 53 n. 31.

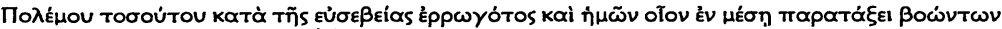

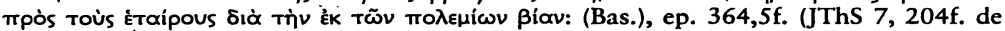
Riedmatten); ET: Deferrari, Letters, vol. 4, 345. H. de Riedmatten, Basile, JThS 8 (see note 58 ), 58.

61 W.-D. Hauschild (ed.), Basilius von Caesarea, Briefe. Dritter Teil, BGrL 37, Stuttgart 1993, 254.

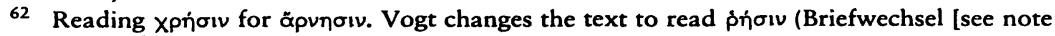
58], 53f. n. 33).

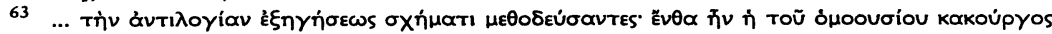

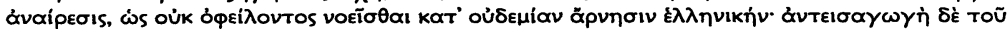

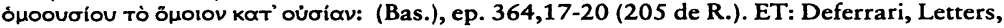
vol. 4, 345 (with amendments).

(Bas.), ep. 364,21-23 (205 de R.). 
argument clearly is polemical; the likeness of statue and emperor is evidently not a likeness of ousia, but one of archetype and image. Its use does, however, betray Apollinarius' acquaintance with a further writing from that time, the pseudo-Athanasian Refutatio hypocriseos Meletii et Eusebii Samosatensis ${ }^{65}$ "to the existence of which", as Chadwick once remarked, "Apollinaris' letter to Basil is ... the earliest witness"66. This brief, polemical treatise, originating in all likelihood from the Antiochene Paulinians, is in its entirety devoted to the argument that the Meletian confession is a distortion of genuine Nicenism.

Even more important for the present investigation may be a second link to which the Apollinarian letter points. It mentions a 'visit from the bishops of Egypt' on which occasion 'documents were distributed' reaffirming the (genuine) faith of Nicaea ${ }^{67}$. De Riedmatten opined that the writing referred to is the Athanasian Ad Jovianum which is, in Theodoretus, a letter from an Athanasian synod ${ }^{68}$. That this synod took place at Antioch had been argued by Valesius ${ }^{69}$, but under the influence of Montfaucon ${ }^{70}$ this view has been universally rejected and even, it seems, been forgotten. Brennecke at any rate, who perceives that the letter cannot have been issued by an Alexandrian synod in early September, resorts to the assumption of a later rewriting of the text ${ }^{71}$. It would appear, however, that a date in December 363 / January 364 would make the present text fit its historical context excellently. Of crucial relevance here is the observation that in this epistle Athanasius himself has effectively revoked his earlier, favourable attitude towards the new Nicenes. Without sharing their polemical extravagances he here is in principal agreement with both the author of the Refutatio and Apollinarius. He would, indeed, appear to draw on the former treatise where he writes:

They pretend to confess it (sc. the Nicene Creed), but in truth they deny it. They misinterpret the homoousion and blaspheme against the Holy Spirit by saying that it is a creature and a product made through the Son ${ }^{72}$.

65 Ath., ref. (PG 28, 85-90); for a German translation of this text cf.: Vogt, Briefwechsel (see note 58$), 58-59$.

o6 G.L. Prestige, St Basil the Great and Apollinaris of Laodicea, ed. by H. Chadwick, London 1956, ix.

67 (Bas.), ep. 364,13-15 (205 de R.).

68 H. de Riedmatten, Basile (see note 58), 58f.; Thdt., h.e. IV 3 (GCS Theodorct, 212,11. 216,7 Parmentier/Hansen).

ay PG 82, $1563 f$.

-o PG 26, 811 .

iH.Ch. Brennecke, Homöer (see note 1), 171 esp. n. 83. Similarly L.W. Barnard (Athanasius (see note 48), 386) who opines that the line in Theodoretus must be spurious.

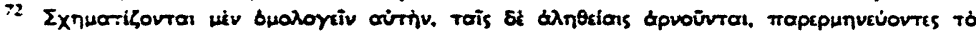

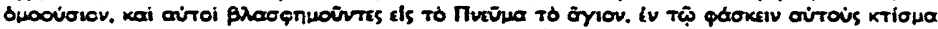

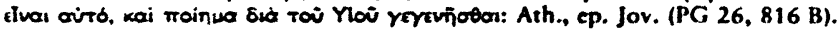


No 'blasphemy' against the Holy Spirit is to be found in the Meletian epistle, but the Refutatio argues that this is implied by its insistence on 'impassible generation'. This would leave no room for the 'breathing' ( $\pi$ UẼ̄ots) of the Holy Spirit from God:

It would be impossible for the Spirit to be honoured in the glory of the Trinity if it does not proceed from God through the Son, but is generated from God as a creature, as they say ${ }^{73}$.

From this statement the Athanasian epistle seems to offer an epitome. While it would appear likely that the Refutatio, if it is indeed the work of the Antiochene Paulinians, would not have been written at a time when Athanasius was still actively trying to enter into communion with Meletius, the same must be true of the Athanasian Ad Jovianum. The latter, therefore, must date from after the eventual breakdown of the Alexandrian's attempts. It would, of course, be tempting to think that the fragmentary letter cited above contained the invitation to this synod. Athanasius, then, would at that point have hoped for a council, perhaps even in the presence of the emperor, uniting old and new Nicenes. In the meantime, however, those hopes had faded, and it was only left for the synod to confirm the newly increased rupture.

While all this, of course, remains speculation, the following reconstruction of events seems to me to offer the best account available to date of those momentous months. After his arrival at Antioch Athanasius continued with his efforts to persuade the new Nicenes into a Nicene alliance with himself. He probably looked forward to the expected gathering of bishops around Meletius hoping for some sign indicating their willingness to terminate the controversy. As nothing of this kind happened and Meletius himself continued to reject him, he decided, some time in late November/December, to consider the attempt failed. He then allowed the Eustathians to write the Refutatio (I cannot believe it to be written without Athanasius' tacit approval); the synod, in December or January, becomes effectively the counterpart to the Alexandrian gathering of the year before in documenting Alexandria's rejection of new Nicenism. Soon afterwards, in late January/February, Apollinarius informs Basil, not quite impartially, of what has taken place hoping to win him over for the old Nicene party.

Against this reconstruction it may be objected that it does not take into account sufficiently the relevance of Paulinus and Meletius as rival bishops of Antioch. Accounts of that period usually explain the rupture between Meletius and Athanasius in 363 with the consecration of Paulinus, head of the Eustathian, old Nicene minority at Antioch, by Lucifer of

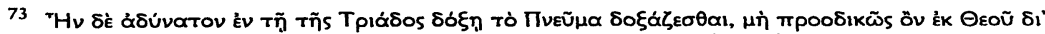

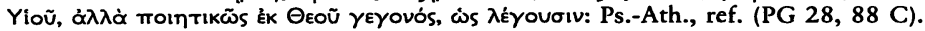


Calaris $^{74}$; on account of his strong ties with the Eustathian community, it is argued, Athanasius could eventually not accept Meletius ${ }^{75}$.

Now it is clear from all the texts that have been investigated that there is no indication of Athanasius' not accepting Meletius as bishop of Antioch. On the contrary, it was the latter who, apparently, rejected the Alexandrian pope. Yet, could not this rejection have been conditioned by the consecration of Paulinus? It would, admittedly, be difficult to answer the question thus put unequivocally in the negative. The following considerations would, however, appear to weaken substantially the case for such an assumption. To begin with a fairly general observation, the need to emphasise the importance of Paulinus for Meletius' behaviour in 363 seems to be due to two implicit assumptions often made by scholarship which I have argued to be unjustified: first, that Meletius' move towards Nicenism would have naturally led him towards an alliance with Athanasius; it thus needs an extra reason to explain why this alliance did not emerge. The second assumption is that Meletius in 362 was party at the Alexandrian synod and thus in principle prepared to enter into communion with Alexandria. Again his change of mind would need to be accounted for. Yet with those two premises removed and Meletius, probably, equally opposed to communion with Athanasius in both 362 and 363 this need has vanished also.

Apart from this it is striking that the consecration of Paulinus and its recognition by Alexandria is mentioned in fourth-century sources much less frequently than one should expect given the emphasis put upon these facts by modern historiography. Basil, e.g., writing to Epiphanius about the Antiochene schism makes no reference to the consecration although he discusses Athanasius' attempts to enter into communion with Meletius and the rival claims of the two bishops. The consecration by Lucifer was clearly uncanonical, and Basil could have employed it in favour of his ally, Meletius. Equally, in his aforesaid letter to Meletius (Epistle 89) Basil treats of the relationship between his friend and Athanasius with no mention of Paulinus. Further, he clearly intimates that Athanasius would be prepared to enter into communion with Meletius now, in 372, if only the latter approached him: but if, as is normally admitted on the basis of Basil's Epistle 214 ${ }^{76}$, Athanasius at some point accepted Paulinus as bishop of Antioch, then there would have been no chance of reconciliation save by settling the legitimacy of the bishopric. Now Basil's attitude with regard to the latter problem is crystal clear and in favour of Meletius; thus, in brief, he could not have written to Meletius like this had the rupture been chiefly about Athanasius' relationship with Paulinus.

\footnotetext{
74

Cf. Socr., h.e. III 6 (197,1-11 H.).

7 Cf., e.g., H.Ch. Brennecke, Homöer (see note 1), 178.

i6 Bas., ep. 214,2 (2, 20S,14-20 C).
} 
Incidentally, there seems to be little evidence that Athanasius at any time formally recognised Paulinus as bishop. Basils's Epistle 89, as I noted, is not easily reconciled with this assumption. What is more, when Epiphanius came to Antioch, probably in or around 374, Paulinus produced the Tomus ad Antiochenos to prove his communion with the Alexandrian pope ${ }^{77}$; he obviously did not possess any more far-reaching statement. It would thus appear likely that the writing from Athanasius the Paulinians showed to Terentius, i.e. the one referred to in Basil's Epistle 214, is again the same Tomus and thus no evidence for Alexandria's official recognition of the Bishop Paulinus ${ }^{78}$. But whatever the precise nature of Athanasius' attitude to Paulinus' bishopric was, it would appear most likely that in 363 he would as readily have set aside the particular interests of his ally as he evidently did the year before and, apparently, was prepared to do in 372. Paulinus, from the point of view of Athanasius, was a pawn; I cannot think the latter would have hesitated to sacrifice this pawn at any given point to salvage his own far-reaching political ambitions.

4.

The brief conclusion is this: while it is often thought that neo-Nicenism when it originated in the 360's was separated from Athanasius by a different trinitarian theology but interested, in principle, in a rapprochement with the latter, the opposite seems to apply. There is every reason to believe that Meletius and his followers are, in 363, very close to Athanasius as far as their trinitarian thought is concerned. There is, on the other hand, no indication that they were, at that point, interested in any kind of a Nicene alliance integrating the Alexandrian pope. That scholarship has so long been mistaken about this it owes, in all likelihood, to the scarcity of evidence available for this early period of neo-Nicenism. Things change radically with the emergence of Basil of Caesaraea who is the main architect of an attempted rapprochement of all Nicenes while at the same time, I think, responsible for what is new about neo-Nicene trinitarian theology. Due to the abundance of material he was to bequeath to posterity his perspective is largely ours; still it deserves to be recalled that in its early years neo-Nicenism received its shape by people whose ideas, both political and theological, were very different from his.

77 Epiph., haer. 77,20,7f. (434,23-31 H./D.).

78 Cf. W.-D. Hauschild, Basilius. Briefe (see note 61), 186. 


\section{ABSTRACT}

Der Artikel untersucht die erhaltenen Informationen über die meletianische Synode, die 363 in Antiochien stattfand. Dieser kommt besondere Bedeutung zu, da das von ihr verfaßte Synodalschreiben das erste direkte Zeugnis für die Existenz einer neunizänischen Partei in den 360er Jahren ist. Die Analyse dieses Schreibens ergibt, daß seine Verfasser theologisch dem Athanasius nicht fern stehen, wahrscheinlich auch direkt Anregungen von ihm aufgreifen. Die Analyse der historischen Ereignisse im Umfeld der Synode zeigt andererseits, daß diese Neunizäner offenbar kein Interesse an einem Bündnis mit Athanasius hatten. Beides widerspricht der traditionellen Ansicht, nach der der Neunizänismus aus einem politischen Interesse am Bündnis mit Alexandria unter Beibehaltung bzw. Ausarbeitung nicht-athanasianischer Theologumena erklärt wird. Beides läßt sich erklären, wenn man bedenkt, wie stark die Wahrnehmung jener Epoche aus der Optik des Basilius erfolgt, auf den beide Merkmale zutreffen, der aber wohl zunächst keinen Einfluß auf die meletianische Partei ausübte. 